\title{
The curious case of coronary cameral fistula with infective endocarditis: A rare harbinger of a common clinical entity
}

\author{
Enfektif endokardit ile seyreden ilginç bir koroner kameral fistül olgusu: \\ Sık görülen klinik bir durumun habercisi
}

Deepi P. Agrawal $®$, Abhishek S. Joshi $₫$, Sunay NM $®$

Department of Cardiac, Vascular \& Thoracic Surgery, Seth G.S. Medical College and KEM Hospital, Mumbai, Maharashtra, India

\begin{abstract}
Coronary cameral fistula is a rare entity characterized by an abnormal communication between coronary artery and a cardiac chamber. It is congenital and asymptomatic in the majority of patients. A 29-year-old male patient presented with fever and dyspnea for eight months. A coronary cameral fistula arising from the right coronary artery to the right atrium complicating with aortic valve endocarditis was detected on computed tomography angiography. The rarity of the condition and the nuanced complication led to very individualized course of treatment which was optimal for this patient.
\end{abstract}

Keywords: Coronary, endocarditis, fistula, fungal, valve.

Coronary artery fistulas are rare disorders, accounting for 0.2 to $0.4 \%$ of all congenital heart defects. ${ }^{[1]}$ They can be either congenital or acquired with the former being the more common etiology. Since the first described case by Krauss ${ }^{[2]}$ in 1865 , there have been multiple reported cases of coronary fistulas with the right coronary artery (RCA) and left anterior descending artery being the most common as sites of fistulization.

Herein, we report a case of a coronary artery fistula in an adult patient without a history of any prior cardiac surgery, initially masquerading and, then, complicating with infective endocarditis.
$\ddot{O} Z$

Koroner kameral fistül, koroner arter ve kalp boşluğu arasındaki anormal bağlantılar ile karakterize, nadir bir durumdur. Hastaların büyük bir çoğunluğunda doğumsal ve asemptomatiktir. Yirmi dokuz yaşında erkek hasta, sekiz aydır devam eden ateş ve nefes darlığ $\breve{1}_{1}$ ile başvurdu. Bilgisayarlı tomografi anjiyografide sağ atriyuma doğru, sağ koroner arterden köken alan ve aort kapak endokarditi ile seyreden bir koroner kameral fistül izlendi. Bu durumun nadir görülmesi ve incelikli komplikasyonu, hasta için ideal olan, son derece kişiselleştirilmiş bir tedavi sürecine yol açtı.

Anahtar sözcükler: Koroner, endokardit, fistül, fungal, kapak.

\section{CASE REPORT}

A 29-year-old male patient was initially sought medical care for intermittent fever, headache, worsening dyspnea for eight months. On physical examination, a continuous murmur was heard in the aortic area and ejection systolic murmur was heard in all cardiac areas. His initial chest radiograph was normal and electrocardiogram showed sinus tachycardia. Transthoracic echocardiography (TTE) revealed a dilated RCA continuing as a fistula and draining into the right atrium (RA) with vegetation on the aortic valve, causing destruction of leaflets and severe aortic regurgitation (AR) with trivial mitral regurgitation (MR).

Received: November 20, 2020 Accepted: February 06, 2021 Published online: April 26, 2021

Correspondence: Deepi Agrawal, MD. Department of Cardiac, Vascular \& Thoracic Surgery, Seth G.S. Medical College and KEM Hospital, 400012 Mumbai, Maharashtra, India. Tel: +91-9408514125 e-mail: deepi2408@gmail.com

Agrawal DP, Joshi AS, NM S. The curious case of coronary cameral fistula with infective endocarditis: A rare harbinger of a common clinical entity Turk Gogus Kalp Dama 2021:29(2):248-251 


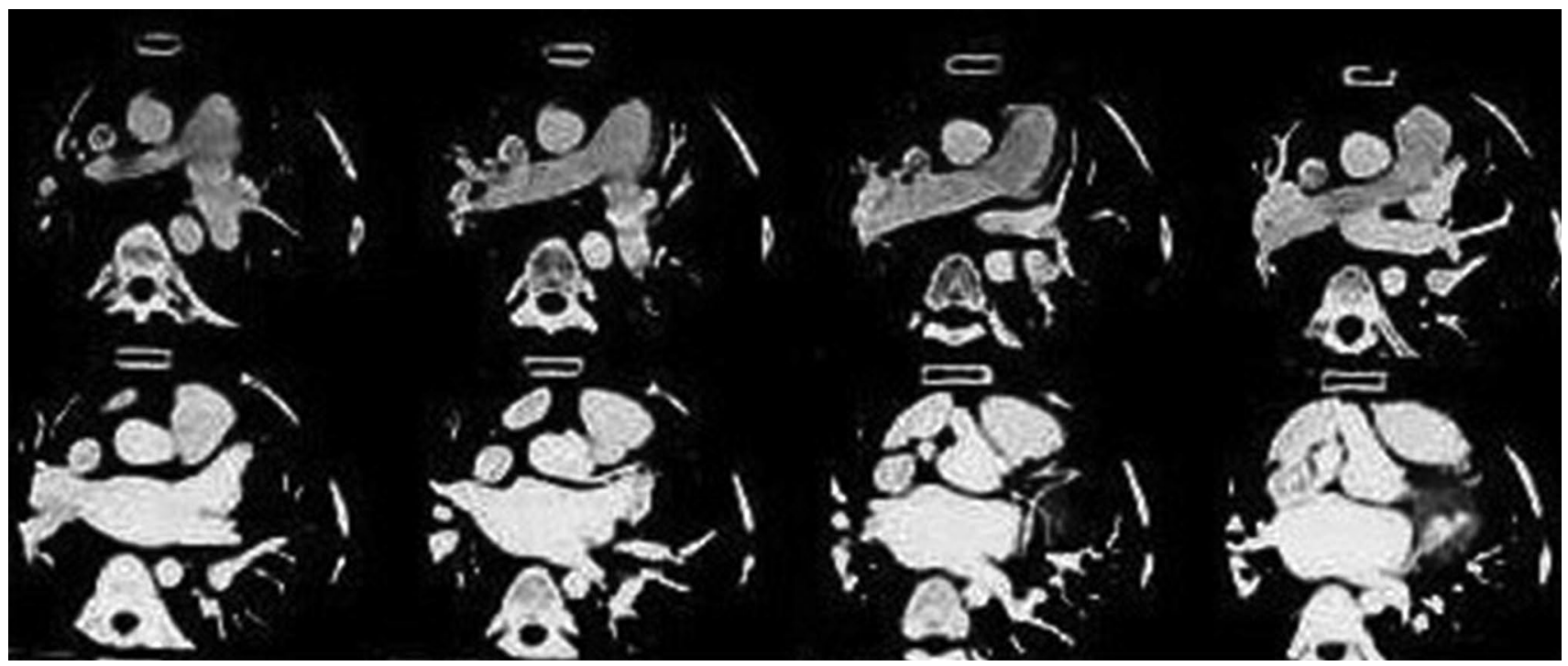

Figure 1. A computed tomographic axial image showing a right coronary artery aneurysm.

Computed tomography (CT) angiography revealed a coronary cameral fistula (CCF) with a markedly dilated origin of the RCA measuring $26.9 \mathrm{~mm}$ (normal size being $4 \mathrm{~mm}$ ) (Figure 1). The ostium of the fistula was seen to open in the RA, which was measured $9.7 \times 9.4 \mathrm{~mm}$ in size. The sinoatrial (SA) nodal artery was seen to arise $36.3 \mathrm{~mm}$ distal to the origin of RCA, where it was measured $20.9 \times 17 \mathrm{~mm}$. The RCA

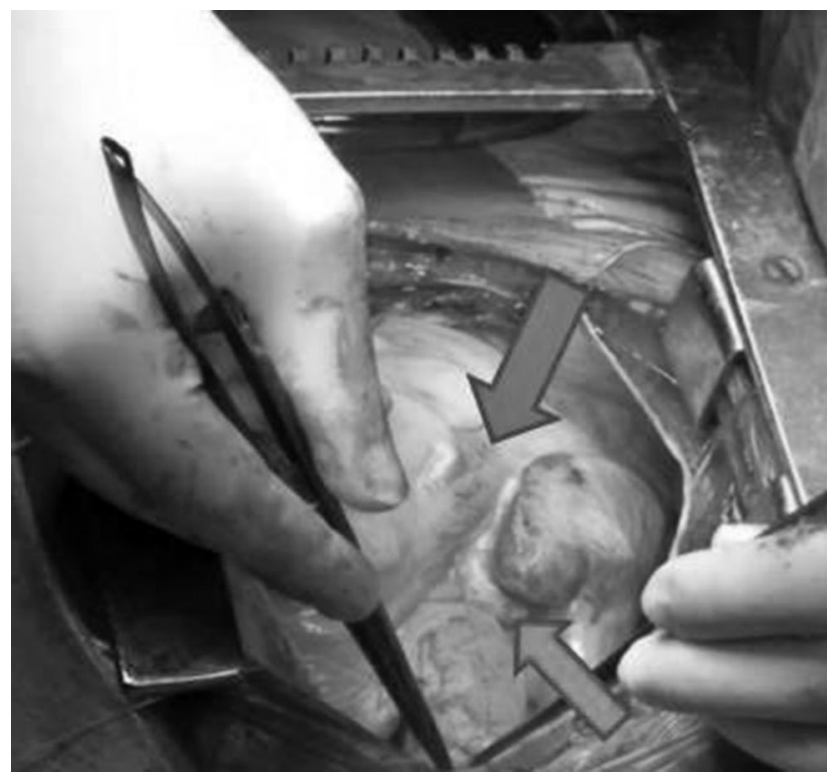

Figure 2. An intraoperative image showing a dilated RCA and sinonodal branch.

RCA: Right coronary artery. distal to the origin to SA nodal artery was normal. Inflammatory markers including $\mathrm{C}$-reactive protein $(64.61 \mathrm{mg} / \mathrm{L})$ and erythrocyte sedimentation rate $(100 \mathrm{~mm})$ were elevated. Broad-spectrum intravenous antibiotics (injectable ceftriaxone plus gentamycin) did not provide a symptomatic improvement and, therefore, a repeat TTE was done to identify which was suggestive of an aortic valve endocarditis with severe AR. Repeat blood culture was positive for the fungus Candida tropicalis (non-Candida albicans), as well as multi-resistant coagulase-negative Streptococci

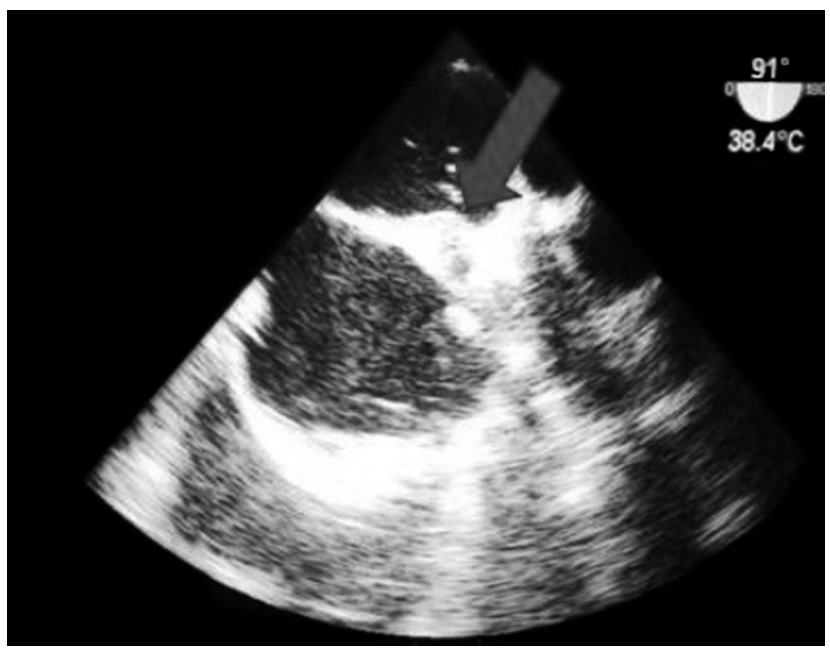

Figure 3. An intraoperative TTE view showing closed fistula after surgery.

TTE: Transthoracic echocardiography. 
(MRCoNS). Definite antimicrobial treatment was initiated, according to the sensitivity in the form of liposomal amphotericin B and double-strength co-trimoxazole along with the vasopressor support in the form of dopamine ( $3 \mu \mathrm{g} / \mathrm{kg} / \mathrm{min})$. Renal function tests and electrolytes were monitored on a daily basis to facilitate early detection of amphotericin-induced nephrotoxicity. There was a symptomatic improvement over the course of the next 10 days and was confirmed microbiologically with a negative blood culture. We planned a CCF repair with aortic valve replacement (AVR) and a written informed consent was obtained.

Surgery was performed under cardiopulmonary bypass using the del $\mathrm{Nido}^{\circledR}$ cardioplegia given directly through the coronary ostia. On opening the aorta, the proximal RCA was found to be aneurysmatically dilated (Figure 2). The SA nodal branch was seen to arise from the RCA with drainage behind the superior vena cava. The aortic valve was a bileaflet valve. The aortic valve leaflets were found to be destroyed due to infective endocarditis; however, there was no evidence of active infective endocarditis. The CCF was closed from inside the RA using a pericardial patch placed with polypropylene-pledgeted sutures $(5-0,13 \mathrm{~mm})$ in an interrupted fashion in two layers (Figure 3). The AVR procedure was done using a 21-mm mechanical bileaflet prosthetic valve (CardiaMed B.V., Uden, Netherlands). The postoperative period was uneventful and the patient was discharged successfully on Day 9 . The post-excision valve specimen was sent for culture analysis which showed no growth and histopathological examination result was suggestive of healed valve endocarditis.

\section{DISCUSSION}

Coronary cameral fistulas are vascular abnormalities in which one or more coronary arteries communicate with a cardiac chamber. Acquired fistulas most commonly occur as complications postcardiotomy done for hypertrophic cardiomyopathy; however, they are rare after coronary artery bypass grafting. In our case, the etiology seems to be congenital.

Qureshi ${ }^{[3]}$ found the origin to be from the RCA in 52 to $60 \%$, the anterior descending artery in $30 \%$, and the circumflex artery in $18 \%$ of the cases. In addition, about $90 \%$ of the fistulas ended up in the right-sided chambers, more frequently in the right ventricle ( $40 \%$ of the cases), followed by the RA, coronary sinus, and pulmonary trunk. The surgical obliteration of the fistula by epicardial or endocardial ligations is the cornerstone of surgical treatment, which was first described by Biorck and Crafoord $^{[4]}$ in 1947.

Without definitive management, around 14\% of CCFs progress to pseudoaneurysm formation. ${ }^{[5]}$ Infective endocarditis is a known complication of CCF and has been addressed by Said $^{[6]}$ in his report of 25 cases. The most common organisms in his article were Streptococci and Staphylococci; however, in our case the etiology was fungal along with MRCoNS. Our patient had a bicuspid aortic valve with a CCF. Although no proven association between these two exists, Qiu et al ${ }^{[7]}$ earlier reported a patient of multiple aortic cameral fistulas with a bicuspid aortic valve.

The final treatment plan was surgical fistula obliteration by placing a pericardial patch inside the $\mathrm{RA}$, as there were sieve-like openings on the RA side of the fistula (Figure 4) along with AVR using a mechanical prosthetic valve to treat this entity. The choice of the valve was dictated by the young age of the patient and optimal antimicrobial response of the abscess. If the antimicrobial therapy failed and infection was persistent, a homograft would have been considered.

Although transcatheter coiling of CCF has been reported in the literature, the presence of concomitant infective endocarditis along with severe $A R$ in our case made surgery the ideal one-step solution. ${ }^{[8]}$

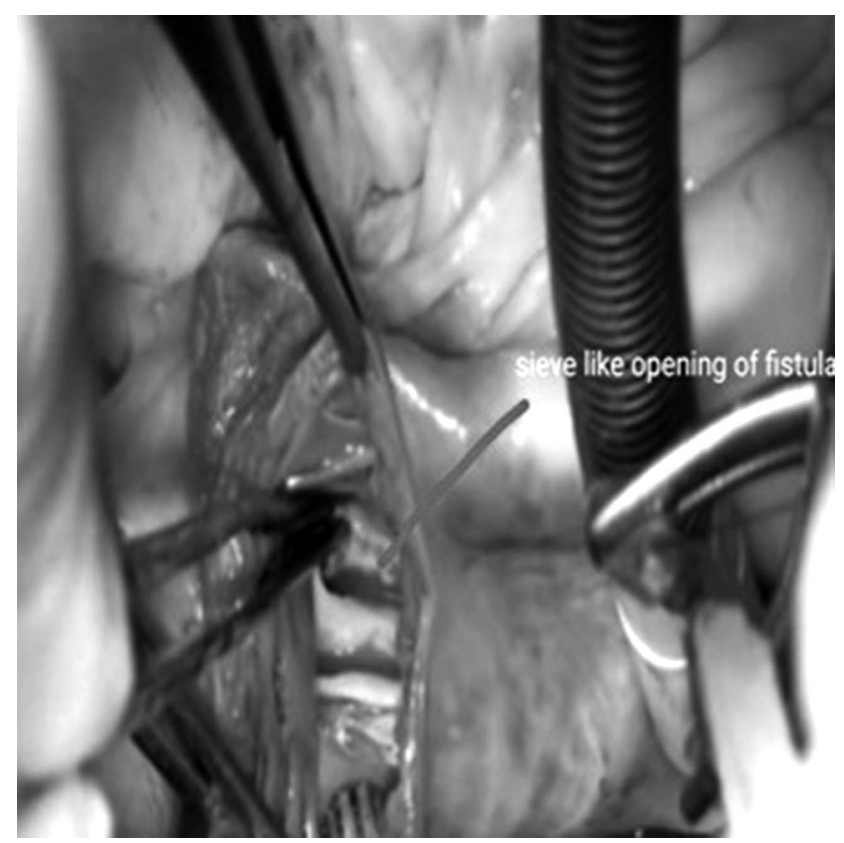

Figure 4. An intraoperative image showing sieve-like opening of fistula in right atrium. 
In conclusion, among the several coronary arteries anomalies, congenital coronary arteriovenous fistulas pose a diagnostic and therapeutic dilemma. Depending on the importance of left-to-right shunt and the steal phenomenon, patients may be symptomatic or asymptomatic. Coronary angiography remains the diagnostic tool. The therapeutic approach to coronary fistulas should consider their anatomical and physiological characteristics to define whether they require management and whether it would be percutaneous or surgical. Both the percutaneous and surgical approaches have their merits and demerits; however, due to the rarity of the condition and the often nuanced and idiosyncratic progression, the treatment should be deliberated and individualized on a case-by-case basis.

\section{Declaration of conflicting interests}

The authors declared no conflicts of interest with respect to the authorship and/or publication of this article.

\section{Funding}

The authors received no financial support for the research and/or authorship of this article.

\section{REFERENCES}

1. Kardos A, Babai L, Rudas L, Gaál T, Horváth T, Tálosi L, et al. Epidemiology of congenital coronary artery anomalies: A coronary arteriography study on a central European population. Cathet Cardiovasc Diagn 1997;42:270-5.

2. Krauss W. Ueber den Ursprung einer accessorischen a. coronaria cordis aus der a. pulmonalis. Z Ratl Med 1865;24:225-9.

3. Qureshi SA. Coronary arterial fistulas. Orphanet J Rare Dis 2006;1:51.

4. Biorck G, Crafoord C. Arteriovenous aneurysm on the pulmonary artery simulating patent ductus arteriosus botalli. Thorax 1947;2:65-74.

5. Said SM, Burkhart HM, Schaff HV, Connolly HM, Phillips $\mathrm{SD}$, Suri RM, et al. Late outcome of repair of congenital coronary artery fistulas--a word of caution. J Thorac Cardiovasc Surg 2013;145:455-60.

6. Said SA. Characteristics of congenital coronary artery fistulas complicated with infective endocarditis: Analysis of 25 reported cases. Congenit Heart Dis 2016;11:756-65.

7. Qiu XB, Shi HY, Liu L, Chen H, Wu WH, Qiu ZK, et al. Multiple aortico-cameral tunnels associated with bicuspid aortic valve in aged: A case report. Chin Med J (Engl) 2009;122:2184-5.

8. Nkya DA, Sinyangwe G, Takawira FF. Transcatheter occlusion of giant congenital coronary cameral fistulae: A case series. J Med Case Rep 2019;13:307. 